\title{
The Effect of Low-Level Laser Therapy on the Acceleration of Orthodontic Tooth Movement
}

\author{
Maryam Baghizadeh Fini ${ }^{1 *}$, Pooya Olyaee ${ }^{2}$, Ahmadreza Homayouni ${ }^{3}$ \\ 'DDS, School of Dentistry, Tehran University of Medical Sciences, Tehran, Iran \\ ${ }^{2}$ DDS, MSc in Orthodontics, MSc in Implantology, Faculty of Dentistry, Goethe University, Frankfurt, Germany \\ ${ }^{3}$ Industrial Engineering and Management Department, Oklahoma State University, US
}

\author{
*Correspondence to \\ Maryam Baghizadeh Fini, \\ Address: 1208 N. Knoblock, Apt \\ 8, Stillwater, OK. \\ Tel: +1 (405) 334-1239; \\ Email: \\ m.baghizadeh92@gmail.com,
}

Published online March 15, 2020

\begin{abstract}
In clinical practice, low-level laser therapy (LLLT) is widely used. The main aim of this review is to assess the effectiveness of LLLT in accelerating tooth movement in human subjects. The PRISMA checklist was utilized as a guideline to carry out this systematic review. The electronic databases were searched from Google Scholar (2014-2018) and PubMed, and comprehensive research on this topic was also manually conducted. Therefore, 77 articles randomized clinical trials (RCTs) or controlled clinical trials (CCTs) were selected. After screening studies, consequently, eleven trials met the inclusion criteria. Eight out of 11 studies showed LLLT has a significant impact on the acceleration of orthodontic tooth movement, and there was no statistically significant difference in the rate of tooth movement between the laser group and the control group in the two remaining studies. Furthermore, five out of 11 articles showed that LLLT has no adverse effects. Although we have some degree of understanding from a cellular point of view to LLLT effects, we still do not know whether these cellular level changes have any effect on the clinical acceleration of orthodontic tooth movement. The results are inconclusive and cannot be generalized to the public community; therefore, well-structured studies are required.

Keywords: Low-level light therapy; Acceleration; Orthodontics.
\end{abstract}

\section{Introduction}

Orthodontic treatment is a popular dental procedure for establishing anesthetic, stable and functional occlusion. The average time for orthodontic treatment is mostly 24 to 36 months. In general, a long-term therapy period is a primary reason for patients to reject this treatment modality. ${ }^{1}$ Root resorption, caries, and decreased patient compliance are more frequent in extended treatment protocols. Therefore, accelerating orthodontic tooth movement is appropriate to prevent those side effects and it can motivate patients to go through the treatment.

Orthodontic treatment is generally based on the rule of bone remodeling resulting from the application of forces to a tooth, building areas of tension and pressure on the periodontal ligament. Acute followed by chronic inflammation and then again acute inflammation (after orthodontic forces reactivation) characterize the process. These modifications in periodontal tissues result in bone remodeling, which is crucial for orthodontic tooth movement. ${ }^{2-4}$

By now, many studies have investigated various ways of accelerating tooth movement, including injections of the drug, electric stimulation, corticotomy, pulsed electromagnetic fields, and mechanical and physical methods. ${ }^{5,6}$

In clinical practice, low-level laser therapy (LLLT) is widely used. ${ }^{7}$ Several parameters describe LLLT. These are as per the following ${ }^{8}$ : (1) Laser power: it ranges from $10^{-3}$ to $10^{-1} \mathrm{~W}$; (2) Wavelength: it ranges from 300 to $10600 \mathrm{~nm}$; (3) Pulse rate: it ranges from 0 to $5000 \mathrm{~Hz}$; (4) Intensity: it ranges from $10^{-2}$ to $10^{2} \mathrm{~J} / \mathrm{cm}^{2}$; and (5) Electromagnetic spectrum: therapeutic lasers range from 630 to $980 \mathrm{~nm}$ in visible red to almost visible red. The utilization of LLLT has been demonstrated to have a useful efficacy in pain alleviation, wounds and nerve damage. ${ }^{9-11}$ The application of LLLT in orthodontics has proven to be advantageous in lowering orthodontic pain and in the photobiomodulation that would possibly accelerate orthodontic tooth movement. ${ }^{12}$ Numerous researchers have studied the use of LLLT in accelerating orthodontic tooth movement ${ }^{13-15}$ and have considered the laser to be effective while others achieved the opposite. ${ }^{16,17}$

Hence, it seems desirable to have a systematic review of current knowledge. This review aims at conducting a thorough assessment of the effect of LLLT on accelerating tooth motion in orthodontic treatment in human subjects. 


\section{Methods}

The PRISMA checklist was utilized as a guideline to carry out this systematic review. ${ }^{18}$

\section{Eligibility Criteria}

Inclusion criteria were as per the following: the study should assess the effectiveness of lasers in accelerating orthodontic tooth movement. Study design: an randomized clinical trial (RCT) or controlled clinical trial (CCT). It is necessary to provide relevant information. Participants: patients who are systematically healthy but in need of orthodontic treatment. Intervention type: subjects should be allocated to experimental or control/ placebo groups depending on whether they receive the laser. Outcome variables: speed or moved distance of tooth motion during treatment.

Exclusion criteria were as per the following: Reviews and primary studies included cohort studies, case-control studies, case series, case reports, descriptive studies, opinion articles, and abstracts, repeated publications, animal experiments, patients with systematic diseases influencing bone metabolism or orthodontic treatment, patients under medical care who may interfere with bone metabolism or orthodontic motion (e.g., analgesics, antiinflammatory medicine or antibiotics), utilization of a high-level laser.

Information Sources, Search Strategy, and Study Selection The electronic databases were searched from Google Scholar (2014-2018) and PubMed using the following keywords: orthodontic, movement, acceleration. Comprehensive research on this topic was also manually conducted. Fifty-six articles were selected with regard to the title. By reviewing the abstracts and considering the increasing laser application in the dentistry field, the laser effect on the orthodontic movements' acceleration was selected. As a result, 36 of the articles irrelevant to laser references were removed. A new search was done by adding the "low-level laser" keyword and 21 new references were found.

By reviewing the sources, some of them were deleted: two repetitive cases, one book reference, seventeen review articles, 5 animal researches, 1 article which did not follow the inclusion criteria, and four cases due to lack of access to full-text. Subsequently, the methods and materials of all papers were reviewed and 11 referrals were selected and then the full-text of all references were studied and analyzed in order to find strongly relevant articles to the subject matter assessed, referring to the eligibility criteria.

\section{Data Items and Collection}

A specialized data extraction form was developed. We extracted the general information of the studies, including author, year of publication, country, number of participants along with their age and gender, laser parameters, laser treatment intervals, and outcomes.

\section{Results}

Search Results

By a main electronic search and a hand search, 77 papers were obtained. Eleven trials met the inclusion criteria after screening the title, abstract and/or complete text. The flow diagram of the study inclusion of the systematic review is shown in Figure 1.

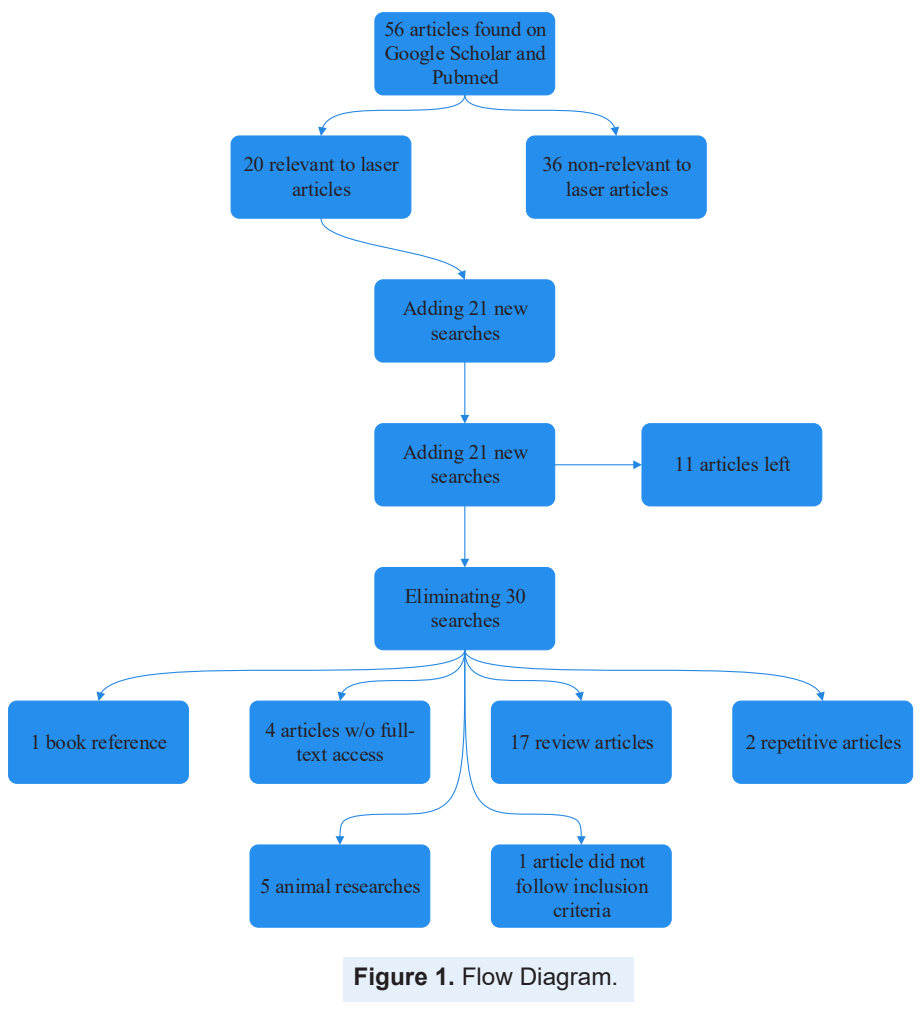


Five RCTs $[12,19,20,22$, and 24] and 6 CCTs $[21,23,25$ 28 ] were finally included. Table 1 shows the specifications of the included studies.

In addition, summary details of laser parameters and treatment intervals are shown in Table 2.

\section{The Impact of LLLT on Orthodontic Tooth Motion}

Guram et $\mathrm{al}^{19}$ : In this study, each quadrant in the maxillary and mandibular arches was divided into laser-treated and control groups. There was a 1.17-1.9-fold increase in the canine tooth movement rate during canine retraction in the laser-treated group. The outcomes were statistically noteworthy.

Dalaie et $\mathrm{al}^{20}$ : The four quadrants were split into lasertreated and control groups at random. Patients initially underwent leveling and alignment using the sectional system; subsequently, Canines were retracted using sectional closing loops. The impact of laser irradiation on the measure of tooth movement was not considerable $(P=0.45)$. Additionally, the amount of movement in the maxilla was equivalent to that in the mandible $(P=0.35)$.

Kansal et $\mathrm{al}^{21}$ : Left and right quadrants of the upper arch were randomly divided into the laser group and the control group to assess the efficacy of LLLT in the rate of

Table 1. The Specifications of the Included Studies

\begin{tabular}{|c|c|c|c|}
\hline Study ID & Study Design & Country & Number of Participants/Age/Gender \\
\hline Guram et $\mathrm{al}^{19}$ & RCT & & 20 participants; 8 males and 12 females; $17-24$ years \\
\hline Dalaie et $\mathrm{al}^{20}$ & RCT & Iran & 12 participants; 3 males and 9 females; mean age 20.1 years \\
\hline Kansal et $\mathrm{al}^{21}$ & ССТ & India & 10 participants; Both genders \\
\hline Qamruddin et $\mathrm{al}^{22}$ & RCT & Pakistan & $\begin{array}{l}22 \text { participants, among whom } 2 \text { participants dropped out; } 11 \text { males and } 11 \text { females; Mean } \\
\text { age } 19.8 \pm 3.1 \text { years }\end{array}$ \\
\hline Varella et $\mathrm{al}^{23}$ & Prospective CCT & India & 10 participants; 4 males and 6 females; $14-25$ years \\
\hline Üretürk et $\mathrm{al}^{24}$ & RCT & Turkey & 15 participants; 7 males and 8 females; mean age $16.2 \pm 1.32$ years \\
\hline Sousa et $\mathrm{al}^{25}$ & ССТ & Brazil & 10 participants; 4 males and 6 females; $10.5-20.2$ years \\
\hline AlSayed Hasan et al ${ }^{11}$ & RCT & Syria & 26 participants; $16-24$ years \\
\hline Genc et $\mathrm{al}^{26}$ & ССТ & Turkey & 20 participants; 6 males and 14 females; mean age $17.8 \pm 4.2$ years \\
\hline Youssef et $\mathrm{al}^{27}$ & ССТ & Syria & 15 participants; Both genders; $14-23$ years \\
\hline Heravi et $\mathrm{al}^{28}$ & ССТ & Iran & 20 participants; 3 males and 17 females; mean age $22.1 \pm 5.3$ \\
\hline
\end{tabular}

Table 2. Laser Parameters and Treatment Intervals

\begin{tabular}{|c|c|c|c|c|c|c|}
\hline Study ID & Type of Laser & Wavelength & Energy Density & Power Output & Exposure Time/Point & Laser Treatment Intervals \\
\hline Guram et al ${ }^{19}$ & Ga-Al-As & $810 \mathrm{~nm}$ & $5 \mathrm{~J} / \mathrm{cm}^{2}$ & $200 \mathrm{~mW}$ & $5 \mathrm{~s}$ & Weekly for 21 days \\
\hline Dalaie et $\mathrm{a}^{20}$ & Ga-Al-As & 880 nm & $5 \mathrm{~J} / \mathrm{cm}^{2}$ & & $10 \mathrm{~s}$ & \\
\hline Kansal et $\mathrm{al}^{21}$ & Ga-As & 904 nm & $4.2 \mathrm{~J} / \mathrm{cm}^{2}$ & $12 \mathrm{~mW}$ & $10 \mathrm{~s}$ & $\begin{array}{l}\text { On } 1^{\text {st }}, 3^{\text {rd }}, 7^{\text {th }}, 14^{\text {th }}, 21^{\text {st }}, 28^{\text {th }}, 35^{\text {th }}, 42^{\text {nd }}, 49^{\text {th }}, 56^{\text {th }} \\
\text { days during the canine retraction phase }\end{array}$ \\
\hline Qamruddin et $\mathrm{al}^{22}$ & Ga-Al-As & $940 \mathrm{~nm}$ & $7.5 \mathrm{~J} / \mathrm{cm}^{2}$ & $100 \mathrm{~mW}$ & $3 \mathrm{~s}$ & $\begin{array}{l}\text { Every } 3 \text { weeks for } 3 \text { more consecutive visits ( } \mathrm{T} 1 \\
\text { and } \mathrm{T} 2 \text { ) }\end{array}$ \\
\hline Varella et $\mathrm{al}^{23}$ & Ga-Al-As & $940 \mathrm{~nm}$ & $8 \mathrm{~J} / \mathrm{cm}^{2}$ & $100 \mathrm{~mW}$ & $10 \mathrm{~s}$ & $\begin{array}{l}3 \text { consecutive days at the following intervals: } \\
\text { start of canine retraction, } 4 \text { weeks later, and } 8 \\
\text { weeks later. }\end{array}$ \\
\hline Üretürk et al ${ }^{24}$ & Ga-Al-As & 820 nm & $5 \mathrm{~J} / \mathrm{cm}^{2}$ & $20 \mathrm{~mW}$ & $10 \mathrm{~s}$ & $\begin{array}{l}\text { On day } 1^{\text {st }}, 3^{\text {rd }}, 7^{\text {th }}, 14^{\text {th }}, 21^{\text {st }}, 30^{\text {th }}, 33^{\text {rd }}, 37^{\text {th }}, 44^{\text {th }} \text {, } \\
51^{\text {st }}, 60^{\text {th }}, 63^{\text {rd }}, 67^{\text {th }}, 74^{\text {th }}, 81^{\text {st }}, 84^{\text {th }}, 90^{\text {th }} \text { days }\end{array}$ \\
\hline Sousa et al ${ }^{25}$ & Ga-Al-As & $780 \mathrm{~nm}$ & $5 \mathrm{~J} / \mathrm{cm}^{2}$ & $20 \mathrm{~mW}$ & $10 \mathrm{~s}$ & $\begin{array}{l}\text { Right after the spring activation (T1), } 3 \text { and } \\
7 \text { days after the first application (T2 and T3), } \\
\text { totaling } 9 \text { applications }\end{array}$ \\
\hline $\begin{array}{l}\text { AlSayed Hasan } \\
\text { et al }{ }^{11}\end{array}$ & Ga-Al-As & 830 nm & $2.25 \mathrm{~J} / \mathrm{cm}^{2}$ & $150 \mathrm{~mW}$ & $15 \mathrm{~s}$ & $\begin{array}{l}\text { First month: } 4 \text { times (days } 1,3,7,14 \text { ); starting } \\
\text { from the second month: every } 15 \text { days }\end{array}$ \\
\hline Genc et $\mathrm{a}^{26}$ & Ga-Al-As & 808 nm & $0.71 \mathrm{~J} / \mathrm{cm}^{2}$ & $20 \mathrm{~mW}$ & $10 \mathrm{~s}$ & $\begin{array}{l}\text { On day } 0 \text {, the } 3^{\text {rd }}, 7^{\text {th }}, 14^{\text {th }}, 21^{\text {st }} \text {, and } 28^{\text {th }} \text { days } \\
\text { after the application of the } \mathrm{Ni} \text {-Ti closed-coil } \\
\text { spring }\end{array}$ \\
\hline Youssef et $\mathrm{al}^{27}$ & Ga-Al-As & $809 \mathrm{~nm}$ & $8 \mathrm{~J} / \mathrm{cm}^{2}$ & $100 \mathrm{~mW}$ & $\begin{array}{l}\text { In the cervical } 10 \mathrm{~s} \\
\text { In the middle } 20 \mathrm{~s} \\
\text { In the apical } 10 \mathrm{~s}\end{array}$ & $\begin{array}{l}\text { On days } 1,3,7 \text {, and } 14 \text { intervals after every } \\
\text { activation }\end{array}$ \\
\hline Heravi et $\mathrm{al}^{28}$ & Ga-Al-As & $810 \mathrm{~nm}$ & $21.4 \mathrm{~J} / \mathrm{cm}^{2}$ & $200 \mathrm{~mW}$ & $30 \mathrm{~s}$ & $\begin{array}{l}\text { Started on the day of attaching coil springs and } \\
\text { was repeated on days } 4,7,11,15,28,32,35 \text {, } \\
39,43 \text {, and } 56\end{array}$ \\
\hline
\end{tabular}

Abbreviation: Ga-Al-As, Gallium-aluminum-arsenide. 
canine movement during the canine retraction phase. The average value obtained for the control group from 1st to $63 \mathrm{rd}$ day was $3.30 \pm 2.36 \mathrm{~mm}$ and it was $3.53 \pm 2.30 \mathrm{~mm}$ for the laser group.

Qamruddin et $\mathrm{al}^{22}$ : The maxillary arch was randomly split into the groups of experiments and placebo. After 9 weeks, canine retraction on the laser-treated side (1.60 $\pm 0.38 \mathrm{~mm}$ ) was considerably higher than that on the placebo side $(0.79 \pm 0.35 \mathrm{~mm} ; P<0.05)$. On the lasertreated side, the general motion of the canines was 2.02 times higher than that on the placebo side.

Varella et $\mathrm{al}^{23}$ : In this split-mouth study, at all of the time points, the quantities of canine retraction for the laser group were higher than those for the control canines $(P<0.001)$.

Üretürk et $\mathrm{al}^{24}$ : Right maxillary canines were distalized as the control group while the left maxillary canines were distalized by laser application. In the laser group, the quantity of tooth motion was $40 \%$ higher than that in the control group after 3 months. The quantity of canine distalization in the laser group was significantly different in comparison with the control group $(P<0.01)$.

Sousa et $\mathrm{al}^{25}$ : Mandibular or maxillary canines or both have been assessed during the retraction of the canines. Only one side of the arch was laser irradiated, whereas the other side was considered the control group. The movement of laser-irradiated canines was statistically greater than that of the control group in all evaluated periods $(P<0.05)$.

AlSayed Hasan et $\mathrm{al}^{11}$ : Patients were allocated either to the laser group or to the control group at random. All patients received conventional fixed equipment orthodontic treatment. In addition, the patients in the laser group had an LLL regimen throughout the phases of leveling and alignment. The laser group needed less mean time (81.23 \pm 15.29 days) to complete leveling and arrangement than the control group $(109.23 \pm 14.18$ days; $P<0.001$ ), which indicates a $26 \%$ decrement over the entire treatment time.

Genc et $\mathrm{al}^{26}$ : The laser was applied when the retraction of the maxillary lateral incisors started. The right maxillary lateral incisors were considered as the laser group, whereas the left maxillary lateral incisors comprised the control group. In the laser-treated group, significant differences were observed over time in the distances between the lateral maxillary incisors and the maxillary central incisors compared to the control group $(P<0.001)$.

Youssef et $\mathrm{al}^{27}$ : The canine retraction was accomplished in both upper and lower jaws. The right side of the upper and lower jaw was regarded as the laser group, while the control group was the left side. The speed of tooth motion was greater in the laser-treated side than that in the control side in the two jaws. There was no statistically significant difference between the upper and lower canine mean speed values $(P>0.05)$ and the jaw position did not influence the speed of tooth motion.

Heravi et $\mathrm{al}^{28}$ : The canine retraction was once carried out solely in the upper jaw requiring first premolar extraction on both sides. One half of the higher arch was irradiated and another half was considered as the placebo group. They utilized two techniques to measure the extension of canine distal movement, and no significant difference was distinguished between the controlled and laser-treated sides by any of the measurement techniques.

Table 3 shows all the results of the included studies.

\section{Adverse Effect}

Five out of 11 articles demonstrated that LLLT has no adverse effects. Kansal et $\mathrm{al}^{21}$ showed that the transformations found in both the LG and CG were approximately the same, and there was no evidence of additional radiographic changes during LLLT around the

Table 3. The Outcomes of the Included Studies

\begin{tabular}{|c|c|}
\hline Study ID & Outcomes \\
\hline Guram et $\mathrm{al}^{19}$ & LLLT can reduce the fixed orthodontic tooth movement duration. \\
\hline Dalaie et $\mathrm{al}^{20}$ & $\begin{array}{l}\text { There was no significant difference in terms of tooth movement between the irradiated and non-irradiated sides at any time point } \\
(P>0.05) \text {. }\end{array}$ \\
\hline Kansal et $\mathrm{al}^{21}$ & $\begin{array}{l}\text { There was no statistically significant difference in the rate of tooth movement during canine retraction between the laser group and } \\
\text { the control group. }\end{array}$ \\
\hline $\begin{array}{l}\text { Qamruddin et } \\
\mathrm{al}^{22}\end{array}$ & $\begin{array}{l}\text { Low-level laser irradiation can accelerate orthodontic tooth. } \\
\text { Movement and the Canine retraction was significantly greater on the experimental side compared with the placebo side. }\end{array}$ \\
\hline Varella et $\mathrm{al}^{23}$ & LLLT-facilitated orthodontics is approximately 2 times faster than conventional orthodontics. \\
\hline Üretürk et $\mathrm{al}^{24}$ & Low-level laser application significantly accelerates tooth movement in humans and could shorten the whole treatment duration. \\
\hline Sousa et $\mathrm{a}^{25}$ & A statistically significant increase in the movement speed of irradiated canines. This might reduce orthodontic treatment time. \\
\hline $\begin{array}{l}\text { AlSayed Hasan } \\
\text { et al }{ }^{11}\end{array}$ & LLLT, used with the described parameters, is an effective method for accelerating orthodontic tooth movement in dental crowding cases. \\
\hline Genc et $\mathrm{al}^{26}$ & The application of a low-level laser could significantly accelerate orthodontic movement in humans. \\
\hline Youssef et $\mathrm{al}^{27}$ & LLLT can accelerate movement during orthodontic treatment. \\
\hline Heravi et $\mathrm{al}^{28}$ & LLLT did not accelerate orthodontic tooth movement \\
\hline
\end{tabular}


irradiated area. Youssef et $\mathrm{al}^{27}$ indicated that radiographs had no evidence of harm in the dental and periodontal tissue promoted by LLLT. Sousa et $\mathrm{al}^{25}$ found no statistically significant difference between the LG and CG groups in the resorption of either root or alveolar bone ridge. Üretürk et $\mathrm{al}^{24}$ concluded that all subjects had excellent gingival and periodontal status at all time points of experiment with no significant difference in the plaque index, the gingival index, and the bleeding scores. Varella et $\mathrm{al}^{23}$ showed plaque accumulation was negligible and periodontal decimation was not found in any subject pending the investigation.

\section{Discussion}

A major determinant of orthodontic tooth motion is the method of bone remodeling in the periodontal tissues, ${ }^{29}$ affected by different local and systemic factors like nutrition, age, and medications ${ }^{30,31}$ and internal factors such as cytokines, ${ }^{32,33}$ interleukin- $1 \beta$ (IL-1 $\beta$ ), and prostaglandins (especially PGE2). ${ }^{34,35}$

LLLT has been considered to be effective in relieving pain, healing soft tissues, muscle relaxation, ${ }^{36}$ immune system modulation, ${ }^{37}$ fibroblast proliferation, ${ }^{38,39}$ and nerve damage recovery. LLLT incites vascularization of the bone defect, fracture position, as well as osteoblasts, which can assist the recuperation of hard tissue. ${ }^{40}$

Several reports ${ }^{41,42}$ have demonstrated that LLLT could accelerate tooth motion in animals. Some researchers used clinical trials to assess the effect of LLLT on the speed of OTM, but the findings were divergent. Hence, this systematic review can be favorable and helpful.

Cruz et al, ${ }^{13}$ (first accomplished human subject studies) conducted a 2-month study on 11 patients to evaluate the rate of tooth motion and indicated significantly higher acceleration of canine retraction in the laser-treated group. Eight studies ${ }^{12,19,22-27}$ showed similar results to those obtained by Cruz et al, but 2 studies ${ }^{20,21}$ like Limpanichkul et $\mathrm{al}^{43}$ studied maxillary canine retraction in 12 young adult patients and found no significant differences in the rate of tooth movement over a 3-month period because of high-level energy density, and they stated that there was no significant difference between the LLLT side and the placebo or controlled side.

Generally, the LLLT improved the vitality actions of the cell by upregulating mitochondrial ATP production. ${ }^{44}$ Therefore, the bio-stimulatory impact of LLLT was a result of cell activation. The fundamental method of orthodontic treatment is bone absorption and deposition, identified as bone remodeling promoted by forces. Accountable for bone resorption and bone formation, osteoclasts and osteoblasts are crucial points in this process. ${ }^{45,46}$

Some studies ${ }^{47}$ have verified the effect of the LLLT on stimulating this process of bone remodeling. Speed growth of orthodontic movement following the use of laser irradiation could be observed because of an increased number of osteoclasts and/or activities in the laser-treated area of the animal models. ${ }^{48}$ Similar findings in the proliferation of osteoclasts and osteoblasts, which could influence the activity of each other, have broadly been reported in other relevant studies and bone healing and vascularization seem to accompany this process. ${ }^{49}$ Lately, there has been a deeper understanding that the LLLT has enhanced tooth movement speed by stimulating the RANK/RANKL/OPG system, ${ }^{50,51}$ reflecting the differentiation level of osteoclasts and essential for bone remodeling.

IL- $1 \beta$ has an important role in bone metabolism. ${ }^{52}$ It is discharged by fibroblasts, macrophages, cementoblasts, osteoblasts, lymphocytes, and osteoclasts. During the first phase of orthodontic tooth motion, this is one of the strongest cytokines in the periodontal setting secreted by osteoclasts as an instant response to mechanical stress in the early phase of orthodontic tooth motion and in the later phase by macrophages. In compressed areas of the periodontal ligament, the accumulation of IL- $1 \beta$ was noted. Because osteoclast fusion, survival, and activation correspond to IL- $1 \beta$, this cytokine defines the amount of tooth movement based on the efficiency of alveolar bone remodeling. Furthermore, IL- $1 \beta$ is straightly related to bone resorption since it stimulates the RANKL expression in osteoblasts and periodontal ligament cells and incites osteoclast precursors to be differentiated. ${ }^{53-55}$ The studies conducted by Varella et $\mathrm{al}^{23}$ and Üretürk et $\mathrm{al}^{24}$ showed that the laser group illustrated a higher rise in the levels of IL$1 \beta$ relative to the control group and there was a positive correlation between the levels of IL-1 $\beta$ and the quantities of motion of the tooth at all times.

The low-level laser aims at the mitochondria, cytochrome-c oxidase in the electron transport chain and porphyrins on the cell membrane. When light photons are absorbed, three things happen: the incitement of adenosine triphosphate synthesis by making active the electron transport chain, the provisional stimulation of reactive oxygen species, and the transient emancipation of nitric oxide from its binding site on cytochrome-c oxidase causing growth in cell respiration. ${ }^{56,57}$ These significant variables have a significant role to play in the clinical effectiveness of LLLT. With this in mind, Genc et $\mathrm{al}^{26}$ evaluated the amount of nitrous oxide in the gingival crevicular fluid and finally they showed the measured nitrite and nitrate levels in both the control and laser groups were similar and no statistically significant outcomes were observed.

The biomodulation impact of lasers relies upon the irradiation dose. ${ }^{58}$ Moreover, it was verified that the laser has low-dose biostimulatory impacts. ${ }^{5,59}$ As indicated by former studies, energy densities in the range of 0.71 and $8 \mathrm{~J} / \mathrm{cm}^{2}$ during canine retraction were efficacious in accelerating tooth movement ${ }^{5,60,61}$ contrasted with the group with high-level energy density $\left(20-25 \mathrm{~J} / \mathrm{cm}^{2}\right) .{ }^{43}$ As we can see, all of our reviewed studies used the laser with energy densities between 0.71 and $8 \mathrm{~J} / \mathrm{cm}^{2}$. 
Various parameters have been shown to be efficient for different lasers; however, optimal quantities have not yet been found out exactly. ${ }^{62}$ All of the protocols are empirical and there is no agreement for them. In addition, a perfect intermediation plan for LLLI has not been set up so far; however, it has been recommended that the application be at the onset of OTM and be applied several times instead of once. ${ }^{63}$ This recommendation has been applied in all our studies.

Ten out of 11 studies reviewed ${ }^{19-27}$ were a split-mouth study, which is a strong point of the studies because the environment conditions for both control and laser groups are the same, so it makes the results more realistic. Only in the study by AlSayed Hasan et $\mathrm{al}^{24}$ used two groups each with 13 patients.

In the study by Qamruddin et $\mathrm{al},{ }^{22}$ an important point, which we recommend that researchers use it in future studies, is that a plastic shield was utilized as an obstacle having the same wavelength as the laser so as to prohibit the carry-across result which is a conceivable disadvantage of split-mouth studies. Moreover, OTM evaluations made errors in almost all studies because of anchorage losses related to tooth motion, which was not considered, but in the studies conducted by Qamruddin et $\mathrm{al}^{22}$ and Varella et $\mathrm{al}^{23}$ palatal rugae were designated as the reference because the palatal rugae are a constant landmark and are not influenced by orthodontic treatment.

When applying the low-level laser in orthodontics, the primarily concerned potential adverse effect of LLLT is harmful to alveolar bone, periodontal tissue, and root, which is usually deemed unfavorable in orthodontic treatment, but no apparent damage has been observed in the alveolar bone, periodontal tissue, and root. Therefore, the insecurity or adverse effects induced by LLLT were not demonstrated. ${ }^{56,63}$

In 2014, Kansal et $\mathrm{al}^{21}$ did the CCT and realized that there were no statistically significant differences in the rate of tooth motion during canine retraction between the laser group and the control group. The possible reason for this result may be sample size in this study that was only 10 patients and this could be ascribed to changes in biology, bone characteristics, and canine root posture in the cortical plates. These variables are likely to be minimized by collecting a much larger sample.

In 2015, Dalaie et $\mathrm{al}^{20}$ carried out a double-blind randomized CCT, the result of which revealed that the influence of laser irradiation on the amount of tooth motion was not significant $(P=0.45)$. This result may be due to differences in radiation parameters; in addition, the small number of evaluated patients, only 12 , can also have some effects on the result of the study.

In 2014, Heravi et $\mathrm{al}^{28}$ did a single-blind CCT and concluded that LLLT has no significant impact on canine movement velocity. It is possible that these findings are because of differences in radiation parameters.

In spite of the fact that this systematic review was carried out intently according to standard methods, there were still a few constraints. First, although a plenary literature search was conducted, just 11 studies were included in this survey. Second, the methodological heterogeneity and the lack of comparability of the main results can impress the qualitative summary of this study. Third, the language limitation in search of literature could have brought bias into this review. Fourth, some studies did not elaborate the information we required in the article. Although we attempted to contact the researchers, there was no response.

Although we have some degree of understanding from a cellular point of view to LLLT effects, we still do not know whether this cellular level changes have any effect on the clinical acceleration of orthodontic tooth movement. The results are inconclusive and cannot be generalized to the public community; therefore, well-structured studies are required to eliminate bias in order to get into a better knowledge of the LLLT effect on the acceleration of orthodontic tooth motion.

\section{Ethical Considerations}

Not applicable.

\section{Conflict of Interests}

The authors declare no conflict of interest.

\section{References}

1. Yoshida T, Yamaguchi M, Utsunomiya T, Kato M, Arai Y, Kaneda T, et al. Low-energy laser irradiation accelerates the velocity of tooth movement via stimulation of the alveolar bone remodeling. Orthod Craniofac Res. 2009; 12:289-298. doi: 10.1111/j.1601-6343.2009.01464.x.

2. Vandevska-Radunovic V. Neural modulation of inflammatory reactions in dental tissues incident to orthodontic tooth movement. A review of the literature. Eur J Orthod. 1999; 21:231-247. doi: 10.1093/ejo/21.3.231.

3. Ghajar K, Olyaee P, Mirzakouchaki B, Ghahremani L, Garjani A, Dadgar E, et al. The effect of pregnancy on orthodontic tooth movement in rats. Med Oral Patol Oral Cir Bucal. 2013;18(2):e351-e355. doi: 10.4317/ medoral.18465.

4. Olyaee P, Mirzakouchaki B, Ghajar K, Seyyedi SA, Shalchi M, Garjani A, et al. The effect of oral contraceptives on orthodontic tooth movement in rat. Med Oral Patol Oral Cir Bucal. 2013;18(1):e146-e150. doi: 10.4317/medoral.18048.

5. Ge MK, He WL, Chen J, Wen C, Yin X, Hu ZA, et al. Efficacy of low-level laser therapy for accelerating tooth movement during orthodontic treatment: a systematic review and meta-analysis. J Lasers Med Sci. 2015;30(5):1609-18. doi: 10.1007/s10103-014-1538-z.

6. Kau CH, Kantarci A, Shaughnessy T, Vachiramon A, Santiwong P. Photobiomodulation accelerates orthodontic alignment in the early phase of treatment. Prog Orthod. 2013;14:30. doi: 10.1186/2196-1042-14-30.

7. Long H, Zhou Y, Xue J, Liao L, Ye N, Jian F, et al. The effectiveness of low-level laser therapy in accelerating orthodontic tooth movement: a meta-analysis. J Lasers Med Sci. 2015;30(3):1161-70. doi: 10.1007/s10103-013-1507-y. 
8. Saquib S, Jadhav V, Priyanka N, Perla N. Low level laser therapy in dentistry: A review. Int J Contemp Dent Med Rev. 2014; 2014. doi:10.15713/ins.ijcdmr.24

9. Midamba ED, Haanaes HR. Effect of low level laser therapy (LLLT) on inferior alveolar, mental and lingual nerves after traumatic injury in 15 patients. A pilot study. Laser Ther. 1993;5(2):89-94.

10. Seyyedi SA, Olyaee P, Sani ZD, Falaki F. Low level laser therapy (LLLT) for orofacial pain. J Lasers Med Sci. 2012;3(3):97-101. doi: 10.22037/jlms. v3i3.2769

11. Seraj B, Shahrabi M, Masoumi S, Jabbarian R, Manesh AA, Fini MB. Studying Maxillary Labial Frenulum Types and Their Effect on Median Diastema in 3-6-year-old Children in Tehran Kindergartens. World J Dent. 2019;10(2):93-97. doi: 10.5005/jp-journals-10015-1611.

12. AlSayed Hasan MM, Sultan K, Hamadah O. Low-level laser therapy effectiveness in accelerating orthodontic tooth movement: a randomized controlled clinical trial. Angle Orthod. 2016;87(4):499-504. doi: 10.2319/062716-503.1.

13. Cruz DR, Kohara EK, Ribeiro MS, Wetter NU. Effects of low-intensity laser therapy on the orthodontic movement velocity of human teeth: A preliminary study. Lasers in Surgery and Medicine: Laser Surg Med. 2004;35(2):117-20. doi: 10.1002/lsm.20076.

14. Doshi-Mehta G, Bhad-Patil WA. Efficacy of lowintensity laser therapy in reducing treatment time and orthodontic pain: a clinical investigation. Am J Orthod Dentofacial Orthop. 2012;141(3):289-297. doi: 10.1016/j. ajodo.2011.09.009.

15. Kawasaki, K., and Shimizu, N. Effects of low-energy laser irradiation on bone remodeling during experimental tooth movement in rats. Lasers Surg Med. 2000;26:282291. doi: 10.1002/(sici)1096-9101(2000)26:3<282::aidlsm6>3.0.co;2-x.

16. de Almeida VL, de Andrade Gois VL, Andrade RN, Cesar CP2, de Albuquerque-Junior RL. Efficiency of low-level laser therapy within induced dental movement: a systematic review and meta-analysis. J Photochem Photobiol B. 2016;158:258-266. doi: 10.1016/j.jphotobiol.2016.02.037.

17. Sousa MV, Pinzan A, Consolaro A, Henriques JF, de Freitas MR. Systematic literature review: influence of lowlevel laser on orthodontic movement and pain control in humans. Photomed Laser Surg. 2014;32:592-599. doi: 10.1089/pho.2014.3789.

18. Moher D, Shamseer L, Clarke M, Ghersi D, Liberati A, Petticrew M, et al. Preferred reporting items for systematic review and meta-analysis protocols (PRISMA-P) 2015 statement. Syst Rev. 2015;4(1):1. doi: 10.1186/2046-40534-1

19. Guram G, Reddy RK, Dharamsi AM, Ismail PM, Mishra S, Prakashkumar MD. Evaluation of low-level laser therapy on orthodontic tooth movement: a randomized control study. Contemp Clin Dent. 2018;9(1):105-9. doi: 10.4103/ ccd.ccd_864_17.

20. Dalaie K, Hamedi R, Kharazifard MJ, Mahdian M, Bayat M. Effect of low-level laser therapy on orthodontic tooth movement: a clinical investigation. J Dent (Tehran). 2015;12(4):249-56.

21. Kansal A, Kittur N, Kumbhojkar V, Keluskar KM, Dahiya P. Effects of low-intensity laser therapy on the rate of orthodontic tooth movement: a clinical trial. Dent Res J (Isfahan). 2014;11(4):481-8.

22. Qamruddin I, Alam MK, Mahroof V, Fida M, Khamis MF,
Husein A. Effects of low-level laser irradiation on the rate of orthodontic tooth movement and associated pain with self-ligating brackets. Am J Orthod Dentofacial Orthop. 2017;152(5):622-30. doi: 10.1016/j.ajodo.2017.03.023.

23. Varella AM, Revankar AV, Patil AK. Low-level laser therapy increases interleukin- $1 \beta$ in gingival crevicular fluid and enhances the rate of orthodontic tooth movement. Am J Orthod Dentofacial Orthop. 2018;154(4):535-44. doi: 10.1016/j.ajodo.2018.01.012.

24. Üretürk SE, Saraç M, Firatlı S, Can ŞB, Güven Y, Firatlı E. The effect of low-level laser therapy on tooth movement during canine distalization. Lasers Med Sci. 2017;32(4):75764. doi: 10.1007/s10103-017-2159-0.

25. da Silva Sousa MV, Scanavini MA, Sannomiya EK, Velasco LG, Angelieri F. Influence of low-level laser on the speed of orthodontic movement. Photomed Laser Surg. 2011; 29(3):191-6. doi: 10.1089/pho.2009.2652.

26. Genc G, Kocadereli I, Tasar F, Kilinc K, El S, Sarkarati B. Effect of low-level laser therapy (LLLT) on orthodontic tooth movement. Lasers Med Sci. 2013;28(1):41-7. doi: 10.1007/s10103-012-1059-6.

27. Youssef M, Ashkar S, Hamade E, Gutknecht N, Lampert F, Mir M. The effect of low-level laser therapy during orthodontic movement: a preliminary study. Lasers Med Sci. 2008;23(1):27-33. do: 10.1007/s10103-007-0449-7.

28. Heravi F, Moradi A, Ahrari F. The effect of low level laser therapy on the rate of tooth movement and pain perception during canine retraction. Oral Health Dent Manag. 2014;13(2):183-8

29. Meikle MC. The tissue, cellular, and molecular regulation of orthodontic tooth movement: 100 years after Carl Sandstedt. Eur J Orthod. 2006;28(3):221-40. doi: 10.1093/ ejo/cjl001.

30. Cağlaroğlu M, Erdem A. Histopathologic investigation of the effects of prostaglandin E2 administered by different methods on tooth movement and bone metabolism. Korean J Orthod. 2012;42(3):118-28. doi: 10.4041/ kjod.2012.42.3.118

31. Juneja P, Shivaprakash G, Kambalyal PB. An overview of the role of drugs and systemic factors on orthodontic tooth movement. Journal of Indian Orthodontic Society. 2008; 42:36-47.

32. Garlet TP, Coelho U, Silva JS, Garlet GP. Cytokine expression pattern in compression and tension sides of the periodontal ligament during orthodontic tooth movement in humans. Eur J Oral Sci. 2007;115(5):355-62. doi: 10.1111/j.1600-0722.2007.00469.x.

33. Krishnan V, Davidovitch Z. Cellular, molecular, and tissue-level reactions to orthodontic force. Am J Orthod Dentofacial Orthop. 2006;129(4):469.e1-32. doi: 10.1016/j. ajodo.2005.10.007.

34. Hienz SA, Paliwal S, Ivanovski S. Mechanisms of bone resorption in periodontitis. J Immunol Res. 2015; 2015:615486. doi: 10.1155/2015/615486.

35. Li Y, Jacox LA, Little SH, Ko CC. Orthodontic tooth movement: The biology and clinical implications. Kaohsiung J Med Sci. 2018;34(4):207-14. doi: 10.1016/j. kjms.2018.01.007.

36. Aimbire F, Bjordal JM, Iversen VV, Albertini R, Frigo L, Pacheco MT, et al. Low level laser therapy partially restores trachea muscle relaxation response in rats with tumor necrosis factor $\alpha$-mediated smooth airway muscle dysfunction. Lasers in Surgery and Medicine: Lasers Surg 
Med. 2006; 38(8):773-8. doi: 10.1002/lsm.20357.

37. dos Anjos LM, Salvador PA, de Souza ÁC, de Souza da Fonseca A, de Paoli F, Gameiro J. Modulation of immune response to induced-arthritis by low-level laser therapy. J Biophotonics. 2019;12(2):e201800120. doi: 10.1002/ jbio.201800120.

38. Huang TH, Liu SL, Chen CL, Shie MY, Kao CT. Lowlevel laser effects on simulated orthodontic tension side periodontal ligament cells. Photomed Laser Surg. 2013; 31(2):72-7. doi: 10.1089/pho.2012.3359.

39. Gkogkos AS, Karoussis IK, Prevezanos ID, Marcopoulou KE, Kyriakidou K, Vrotsos IA. Effect of Nd: YAG low level laser therapy on human gingival fibroblasts. Int J Dent. 2015;2015:258941. doi: 10.1155/2015/258941.

40. Kim JR, Kim SH, Kim IR, Park BS, Kim YD. Lowlevel laser therapy affects osseointegration in titanium implants: resonance frequency, removal torque, and histomorphometric analysis in rabbits. J Korean Assoc Oral Maxillofac Surg. 2016; 42(1):2-8. doi: 10.5125/ jkaoms.2016.42.1.2.

41. Duan J, Na Y, Liu Y, Zhang Y. Effects of the pulse frequency of low-level laser therapy on the tooth movement speed of rat molars. Photomed Laser Surg. 2012;30(11):663-7. doi: 10.1089/pho.2012.3220.

42. Alazzawi MM, Husein A, Alam MK, Hassan R, Shaari R, Azlina A, et al. Effect of low level laser and low intensity pulsed ultrasound therapy on bone remodeling during orthodontic tooth movement in rats. Prog Orthod. 2018; 19(1):10. doi: 10.1186/s40510-018-0208-2.

43. Limpanichkul W, Godfrey K, Srisuk N, Rattanayatikul C. Effects of low-level laser therapy on the rate of orthodontic tooth movement. Orthod Craniofac Res. 2006;9(1):38-43. doi: 10.1111/j.1601-6343.2006.00338.x.

44. Ferraresi C, Kaippert B, Avci P, Huang YY, de Sousa MV, Bagnato VS, Parizotto NA, Hamblin MR. Low-level Laser (Light) Therapy Increases Mitochondrial Membrane Potential and ATP Synthesis in C2C12 Myotubes with a Peak Response at 3-6 h. Photochem Photobiol. 2015; 91(2):411-6. doi: 10.1111/php.12397.

45. Yu JH, Huang HL, Liu CF, Wu J, Li YF, Tsai MT,et al. Does orthodontic treatment affect the alveolar bone density? Medicine (Baltimore). 2016;95(10):e3080. doi: 10.1097/ MD.0000000000003080.

46. Rowe P, Sharma S. Physiology, Bone Remodeling. [Updated 2019 Mar 9]. In: StatPearls [Internet]. Treasure Island (FL): StatPearls Publishing; 2020. Available from: https://www. ncbi.nlm.nih.gov/books/NBK499863/.

47. Suzuki SS, Silva Garcez A, Suzuki H. Low-level laser therapy stimulates bone metabolism and inhibits root resorption during tooth movement in a rodent model. J Biophotonics. 2016;9(11-12):1222-1235. doi: 10.1002/jbio.201600016.

48. Fujita S, Yamaguchi M, Utsunomiya T, Yamamoto H, Kasai $\mathrm{K}$. Low-energy laser stimulates tooth movement velocity via expression of RANK and RANKL. Orthod Craniofac Res. 2008;11(3):143-55. doi: 10.1111/j.1601-6343.2008.00423.x.

49. Altan BA, Sokucu O, Ozkut MM, Inan S. Metrical and histological investigation of the effects of low-level laser therapy on orthodontic tooth movement. Lasers Med Sci. 2012; 27(1):131-40. doi: 10.1007/s10103-010-0853-2.

50. Yamaguchi M. RANK/RANKL/OPG during orthodontic tooth movement. Orthod Craniofac Res. 2009;12(2):113-9. doi: 10.1111/j.1601-6343.2009.01444.x.

51. Kasai K, Chou MY, Yamaguchi M. Molecular effects of low-energy laser irradiation during orthodontic tooth movement. Semin Orthod. 2015;21(3):203-209. doi: 10.1053/j.sodo.2015.06.007

52. Lee YM, Fujikado N, Manaka H, Yasuda H, Iwakura Y. IL-1 plays an important role in the bone metabolism under physiological conditions. Int immunol. 2010;22(10):805-16. doi: 10.1093/intimm/dxq431.

53. d'Apuzzo F, Cappabianca S, Ciavarella D, Monsurro A, Silvestrini-Biavati A, Perillo L. Biomarkers of periodontal tissue remodeling during orthodontic tooth movement in mice and men: overview and clinical relevance. ScientificWorldJournap. 2013;2013:105873. doi: 10.1155/2013/105873.

54. Jäger A, Zhang D, Kawarizadeh A, Tolba R, Braumann B, Lossdörfer S, et al. Soluble cytokine receptor treatment in experimental orthodontic tooth movement in the rat. Eur $J$ Orthod. 2005;27(1):1-1. doi: 10.1093/ejo/cjh089.

55. Teixeira CC, Khoo E, Tran J, Chartres I, Liu Y, Thant LM, et al. Cytokine expression and accelerated tooth movement. J Dent Res. 2010;89:1135-41. doi: 10.1177/0022034510373764.

56. Ross G, Ross A. Photobiomodulation: an invaluable tool for all dental specialties. J Laser Dent. 2009;17:117-24.

57. Hamblin MR, Demidova TN. Mechanisms of low level light therapy. Mechanisms of low level light therapy. Proc SPIE. 2006;6140:614001. doi: 10.1117/12.646294.

58. Bolton P, Young S, Dyson M. Macrophage responsiveness to light therapy with varying power and energy densities. Laser Ther. 1991; 3:105-112.

59. Qamruddin I, Alam MK, Khamis MF, Husein A. Minimally invasive techniques to accelerate the orthodontic tooth movement: a systematic review of animal studies. Biomed Res Int. 2015;2015:608530. doi: 10.1155/2015/608530.

60. Yassaei S, Aghili H, Afshari JT, Bagherpour A, Eslami F. Effects of diode laser $(980 \mathrm{~nm})$ on orthodontic tooth movement and IL-6 levels in gingival crevivular fluid in female subjects. Lasers Med Sci. 2016;31(9):1751-1759. doi: 10.1007/s10103-016-2045-1.

61. Angelieri F, Sousa MVS, Kanashiro LK. Effects of low intensity laser on pain sensitivity during orthodontic movement. Dental Press J Orthod. 2011;16:95-102.

62. Van Breugel H, Bar PR. Power density and exposure time of hene laser irradiation are more important than total energy dose in photo-biomodulation of human fibroblasts in vitro. Lasers Surg Med. 1992;12:528. doi: 10.1002/ $1 \mathrm{sm} .1900120512$.

63. Wangsrimonkol T, Manosudprasit M, Pisek P, Chongcharueyskul P. Laser accelerated tooth movement. Thai Assoc Orthod. 2015;5:27-37. 